\title{
Pengaruh Daun Lemna (Lemna minor) Fermentasi pada Pakan terhadap Pertumbuhan Ikan Gurame (Osphronemus gouramy)
}

\author{
The Effect of Fermented Lemna (Lemna minor) Leaf in Feed on the Growth of \\ Gouramy (Osphronemus Gouramy) \\ Khairudin $^{1 *}$, Adelina ${ }^{1}$, Indra Suharman ${ }^{1}$ \\ ${ }^{1}$ Jurusan Budidaya Perairan, Fakultas Perikanan dan Kelautan Universitas Riau \\ email:khairudinmt4@gmail.com
}

(Received: 18 Mei 2021; Accepted: 18 Juni 2021)

\begin{abstract}
ABSTRAK
Penelitian ini dilakukan selama 56 hari dari bulan Februari sampai Maret 2020, yang bertujuan untuk mendapatkan jumlah tepung daun lemna fermentasi terbaik dalam pakan untuk pertumbuhan ikan gurami (Osphronemus gouramy). Ikan gurami yang digunakan memiliki bobot rata-rata 1,74-1,76 g, ikan dipelihara dalam keramba berukuran $1 \times 1 \times 1 \mathrm{~m}$ dengan padat tebar 20 ekor $/ \mathrm{m}^{3}$. Pakan yang digunakan dalam percobaan menggunakan tepung kedelai yang diganti dengan tepung daun lemna fermentasi, sebanyak 0, 10, 15, 20, dan 25\% dengan kandungan protein pakan sebesar 35\%. Pakan diberikan tiga kali sehari sebanyak 10\% dari berat badan. Metode yang digunakan dalam penelitian ini adalah eksperimen satu faktor Rancangan Acak Lengkap (RAL) dengan lima perlakuan dan tiga ulangan. Hasil penelitian menunjukkan bahwa penggunaan daun lemna yang difermentasi dalam pakan mampu menggantikan tepung kedelai dan mempengaruhi laju pertumbuhan ikan gurami. Substitusi daun lemna fermentasi $20 \%$ merupakan perlakuan terbaik, menghasilkan kecernaan pakan 70,23\%, kecernaan protein 81,41, efisiensi pakan 40,31\%, retensi protein $31,05 \%$, laju pertumbuhan spesifik 3,77\%, dan kelangsungan hidup 98,33\%. Hasil pengukuran kualitas air selama penelitian adalah suhu $29-31^{\circ} \mathrm{C}$, $\mathrm{pH} 5-5,6$, dan oksigen terlarut 6-8 ppm.
\end{abstract}

Kata Kunci: Ikan gurami, Daun lemna, Fermentasi, Rumen sapi

\begin{abstract}
This research was conducted for 56 days from February to March 2020, which aimed to obtain the best amount of fermented Lemna minor leaf meal in feed for the growth of gouramy (Osphronemus gouramy). The gouramy used has an average weight of 1.74-1.76 g, fish are reared in cages measuring $1 \times 1 \times 1 \mathrm{~m}$ with a stocking density of $20 \mathrm{fish} / \mathrm{m}^{3}$. The feed used in the experiment used soy flour replaced with fermented lemna leaf flour, as much as $0,10,15,20$, and $25 \%$ with a feed protein content of $35 \%$. Feed is given three times a day as much as $10 \%$ of body weight. The method used in this study was an experimental one-factor completely randomized design (CRD) with five treatments and three replications. The results of the research showed that the use of fermented lemna leaf in the feed was able to replace soybean flour and affect the growth rate of gouramy. Substitution of $20 \%$ fermented lemna leaf was the best treatment, resulting in feed digestibility of $70.23 \%$, protein digestibility of 81.41 , feed efficiency of $40.31 \%$, protein retention of $31.05 \%$, a specific growth rate of $3.77 \%$, and survival rate of $98.33 \%$. The results of water quality measurements during the study were temperature $29-31^{\circ} \mathrm{C}, \mathrm{pH} 5-5.6$, and dissolved oxygen 6-8 ppm.
\end{abstract}

Keyword: Giant gouramy, Lemna leaves, Fermentation, Cow Rumen Fluid.

\section{Pendahuluan}

Salah satu jenis ikan air tawar yang menjadi andalan komoditas perikanan budidaya di Provinsi Riau adalah ikan Gurami (Osphronemus gouramy). Ikan ini mempunyai nilai ekonomis tinggi dan berpotensi cukup 
besar untuk dikembangkan sebagai ikan budidaya. Salah satu cara untuk mempercepat pertumbuhan ikan gurami dapat dilakukan dengan melakukan pemberian pakan yang mempunyai kandungan nutrien (protein, lemak, karbohidrat, vitamin dan mineral) yang memenuhi kebutuhan ikan.

Pada budidaya ikan intensif, penyediaan pakan buatan membutuhkan biaya relatif banyak yaitu sekitar 60-70\% (Suprayudi, 2010). Saat ini hampir semua bahan baku pakan diimpor, termasuk tepung ikan dan tepung kedelai yang merupakan sumber protein hewani dan nabati. Bahan baku tersebut memiliki kadar protein yang tinggi yaitu tepung ikan 50\% dan tepung kedelai 36,18\% (Afrianto dan Liviawaty, 2005). Namun mahalnya harga tepung ikan dan tepung kedelai saat ini menyebabkan harga pakan menjadi tinggi. Oleh karena itu harus ada alternatif bahan baku lokal pengganti tepung ikan dan tepung kedelai yang harganya lebih murah, jumlahnya melimpah dan terjaga kontinuitasnya, sehingga diharapkan dapat mengurangi atau bahkan menggantikan penggunaan tepung ikan dan tepung kedelai tersebut (Suprayudi, 2010).

Salah satu tumbuhan air yang dapat digunakan untuk pakan ikan gurami yaitu Lemna minor. Menurut Solomon dan Okomoda (2012), lemna sebagai bahan pakan memiliki kandungan lebih baik dari kebanyakan protein nabati lainnya dan lebih mirip protein hewani. Tanaman ini mengandung protein sebesar 29,53\% (Said, 2006). Selanjutnya Akter et al. (2011) menyatakan tanaman ini mengandung asam amino esensial seperti lysin 6,9\%, metionin $1,4 \%$ dan histidin 2,7\% sehingga baik digunakan sebagai pakan ikan. Penelitian Nekoubin dan Sudagar (2013) menunjukkan pemberian $20 \%$ L. minor pada ikan grass carp menghasilkan laju pertumbuhan spesifik lebih tinggi dibandingkan dengan tanpa pemberian lemna. Akan tetapi daun lemna memiliki serat kasar yang cukup tinggi yaitu sekitar $29,71 \%$ (Agustono et al., 2010). Oleh sebab itu perlu dilakukan pengolahan bahan baku tersebut sebelum digunakan sebagai bahan baku pakan. Salah satu upaya yang dilakukan yaitu dengan fermentasi (Pamungkas, 2010).

Fermentasi adalah suatu proses untuk meningkatkan daya cerna bahan karena bahan yang telah difermentasi mengalami perubahan dari yang susah dicerna menjadi protein sel tunggal yang lebih mudah dicerna. Pada penelitian ini fermentasi daun lemna dilakukan dengan menggunakan rumen sapi. Cairan rumen sapi mengandung bakteri selulotik yang diharapkan dapat menghidrolisis serat kasar dalam pakan yang menggunakan bahan nabati berserat tinggi, sehingga dapat meningkatkan kecernaan pakan. Penelitian Nalar et al. (2014) menunjukkan bahwa dedak padi yang difermentasi dengan cairan rumen $30 \%$ mengalami penurunan serat kasar dari $9,06 \%$ menjadi $8,87 \%$.

Berdasarkan penjabaran di atas, penulis tertarik melakukan penelitian tentang penggunaan tepung daun L. minor yang difermentasi menggunakan rumen sapi dalam pakan terhadap pertumbuhan benih ikan Gurami sehingga dapat dipakai sebagai bahan alternatif penyusun pakan ikan.

Penelitian ini bertujuan untuk mendapatkan persentase penggunaan tepung daun L.minor terbaik di dalam pakan untuk meningkatkan efisiensi pakan dan pertumbuhan benih ikan gurami.

\section{Metode Penelitian}

\subsection{Waktu dan Tempat}

Penelitian ini dilaksanakan pada bulan Februari - Maret 2020 di UPT Balai Benih Ikan Sei Tibun. Persiapan pakan uji dilakukan di Laboratorium Nutrisi Ikan, Fakultas Perikanan dan Kelautan, Universitas Riau. Analisis kimiawi pakan dilakukan di Laboratorium Teknologi Hasil Pertanian, Fakultas Pertanian, Universitas Riau.

\subsection{Metode Penelitian}

Metode yang digunakan dalam penelitian adalah metode eksperimen dengan menggunakan Rancangan Acak Lengkap (RAL) satu faktor dengan 5 taraf perlakuan dan 3 kali ulangan sehingga diperlukan 15 unit percobaan.

$\begin{aligned} \mathrm{P} 0= & \begin{array}{l}\text { Tepung kedelei 100: Tepung lemna } \\ \text { fermentasi } 0 \%\end{array} \\ \mathrm{P} 1= & \text { TK 90\%: TLF 10\% } \\ \mathrm{P} 2= & \text { TK 85\%: TLF } 15 \% \\ \mathrm{P} 3= & \text { TK 80\%: TLF 20\% } \\ \mathrm{P} 4= & \text { TK 75\%: TLF 25\% }\end{aligned}$




\subsection{Prosedur Penelitian}

\subsubsection{Persiapan Wadah dan Ikan Uji}

Wadah penelitian yang digunakan berupa keramba berukuran 1 x 1 x $11 \mathrm{~m}$ sebanyak 15 unit dan 1 keramba digunakan sebagai tempat stok ikan. Keramba disusun sejajar sebanyak tiga baris dan masing-masing wadah ditenggelamkan pada kolam dengan ketinggian $\pm 75 \mathrm{~cm}$ yang bertujuan agar sinar matahari dapat masuk ke dalam wadah percobaan (keramba) dengan baik.

Ikan uji yang digunakan pada penelitian ini adalah benih ikan gurami yang diperoleh dari Mawar Hatchery Pekanbaru. Jumlah ikan gurami yang digunakan selama penelitian ini sebanyak 400 ekor, ukuran bobot tubuh ratarata ikan 1,74-1,76 g dengan padat tebar setiap wadah 1 ekor/ L ( SNI, 1999).

\subsubsection{Persiapan Tepung Lemna (L. minor)}

Daun lemna yang digunakan adalah daun segar yang memiliki warna hijau, kemudian dicuci bersih menggunakan air mengalir untuk menghilangkan kotoran yang menempel, selanjutnya daun lemna dikeringkan dengan cara dijemur di bawah sinar matahari, dibalik-balik agar semua daun kering. Daun lemna yang sudah kering dihaluskan menggunakan blender hingga menjadi tepung daun lemna.

Cairan rumen yang dipakai berasal dari rumen sapi yang didapat dari Rumah Potong Hewan (RPH) Pekanbaru. Cara pembuatan starter isi rumen mengacu kepada Wuryantoro (2000), adalah sebagai berikut: 1). Air sumur (air yang tidak mengandung bahan kimia seperti kaporit) disiapkan sebanyak $5 \mathrm{~L}$ ke dalam ember plastik berwarna gelap. 2). Isi rumen sapi dimasukkan sebanyak $100 \mathrm{~g}$ ke dalam ember yang telah berisi air tersebut. 3). Gula merah yang sudah dihancurkan sebanyak 200 g ditambahkan air secukupnya untuk menghaluskan gula merah tersebut. 4). Air yang sudah dicampur dengan gula merah diaduk dengan isi rumen hingga bercampur rata. Tujuan diberikan gula merah adalah sebagai sumber energi bagi bakteri untuk tumbuh. 5). Ember ditutup dengan plastik dan inkubasi selama 24 jam. 6). Starter sudah siap digunakan apabila ada warna putih atau buihbuih putih yang mengambang di permukaan wadah. 7). Starter disaring menggunakan saringan kemudian air hasil saringan bisa digunakan sebagai fermentor.

Proses fermentasi tepung daun L.minor dilakukan dengan cara menimbang tepung daun L.minor sebanyak $500 \mathrm{~g}$ dan ditempatkan dalam ember plastik. L.minor kemudian ditambah air sebanyak $500 \mathrm{~mL} / \mathrm{kg}$ dari berat bahan kering. Kemudian diaduk hingga berbentuk seperti bubur, selanjutnya bahan tersebut ditambah starter rumen sapi dengan dosis $500 \mathrm{~mL} / \mathrm{kg}$ dari berat bahan pakan (Chusniati et al., 2005). Setelah itu wadah ditutup rapat untuk diinkubasi selama 24 jam pada suhu ruangan dan $\mathrm{pH}$ diukur. Proses fermentasi L.minor yang berhasil ditandai dengan gelembung gas yang mengambang di atasnya. Setelah proses fermentasi L.minor berhasil, selanjutnya dikeringkan kemudian dihaluskan hingga menjadi tepung dan siap untuk diformulasikan ke dalam pakan.

\subsubsection{Pembuatan Pelet}

Pakan uji yang akan dibuat sebelumnya ditentukan formulasi dan komposisi masingmasing bahan sesuai dengan kebutuhan protein yang dibutuhkan ikan gurami yaitu sebesar 35\%. Proporsi fermentasi lemna minor ditentukan sesuai kebutuhan masingmasing perlakuan, sedangkan bahan-bahan lain disesuaikan jumlahnya berdasarkan hasil perhitungan. Komposisi pakan uji disajikan pada Tabel 1.

Bahan pakan yang digunakan ditimbang sesuai kebutuhan. Pencampuran bahan dilakukan secara bertahap, dimulai dari jumlah yang terendah sampai yang terbanyak hingga campuran homogen. Selanjutnya bahan yang telah homogen tadi ditambahkan air yang telah dimasak (tidak terlalu panas) sebanyak 35 - $40 \%$ dari bobot total bahan. Penambahan air dilakukan sambil bahan diaduk merata sehingga bisa dibuat gumpalangumpalan. Kemudian adonan dicetak menggunakan pencetak pelet dan diteruskan dengan melakukan pengeringan di bawah sinar matahari hingga kering. Pakan yang telah jadi dianalisa proksimat. Hasil analisa proksimat pakan disajikan seperti terlihat pada Tabel 2 . Selanjutnya pakan siap diuji kepada ikan gurami. 
Tabel 1. Komposisi pakan uji

\begin{tabular}{lcccccc}
\hline \multicolumn{1}{c}{ Bahan } & $\begin{array}{c}\text { Protein } \\
\text { Bahan (\%) }\end{array}$ & \multicolumn{5}{c}{ Perlakuan (\%TK : \%TLF ) } \\
\cline { 3 - 6 } & P0 (100:0) & P1 (90:10) & P2 (85:15) & P3 (80:20) & P4 (75: 25) \\
\hline T. Ikan & 50 & 40,0 & 42,0 & 44,0 & 46,0 & 48,0 \\
TLF & 29,53 & 0,0 & 10,0 & 15,0 & 20,0 & 25,0 \\
T.Kedelai & 36,18 & 36,0 & 30,0 & 24,0 & 18,0 & 12,0 \\
T.Terigu & 11 & 18,0 & 12,0 & 11,0 & 10,0 & 9,0 \\
Vit. Mix & 0 & 2,0 & 2,0 & 2,0 & 2,0 & 2,0 \\
Min. mix & 0 & 2,0 & 2,0 & 2,0 & 2,0 & 2,0 \\
M. ikan & 0 & 2,0 & 2,0 & 2,0 & 2,0 & 2,0 \\
\hline Jumlah & & $\mathbf{1 0 0}$ & $\mathbf{1 0 0}$ & $\mathbf{1 0 0}$ & $\mathbf{1 0 0}$ & $\mathbf{1 0 0}$ \\
\hline
\end{tabular}

Tabel 2. Analisa proksimat pakan

\begin{tabular}{lccccc}
\hline \multicolumn{1}{c}{ Parameter } & \multicolumn{5}{c}{ Perlakuan } \\
\cline { 2 - 6 } & P0 & P1 & P2 & P4 & P5 \\
\hline Protein & 29,06 & 30,52 & 31,12 & 32,14 & 31,36 \\
Lemak & 10,88 & 9,86 & 9,12 & 6,56 & 5,74 \\
Serat Kasar & 4,48 & 3,23 & 3,26 & 2,40 & 3,62 \\
Kadar Air & 8,80 & 9,12 & 9,17 & 9,56 & 9,31 \\
Kadar Abu & 20,60 & 20,75 & 20,35 & 21,40 & 24,48 \\
\hline
\end{tabular}

\subsubsection{Pemeliharaan Ikan Uji}

Sebelum ikan uji dimasukkan ke dalam keramba, ikan diadaptasikan terlebih dahulu. Adaptasi ikan dilakukan selama satu minggu dan diberi pakan kontrol. Kemudian ikan dipuasakan selama satu hari untuk mengosongkan saluran pencernaan ikan. Selanjutnya ikan tersebut ditimbang untuk mengetahui bobot awal. Pakan uji diberikan tiga kali sehari yakni pukul 08.00, 12.00 dan 17.00 WIB sebanyak 10\% dari bobot biomassa ikan uji. Pemberian pakan dilakukan selama 56 hari.

\subsubsection{Mengukur Kecernaan Pakan}

Pengujian kecernaan ini dilakukan dengan menambahkan $0,5 \%$ indikator $\mathrm{Cr}_{2} \mathrm{O}_{3}$ dalam pakan perlakuan yang berguna sebagai penanda (marker) (NRC 1993). Pengujian kecernaan pakan dilakukan pada akuarium dengan padat tebar ikan 10 ekor /akuarium dengan dua kali ulangan pada setiap perlakuan. Pakan kemudian diberikan $3 \mathrm{x}$ sehari yaitu pukul $08.00,12.00$ dan 17.00 WIB sebanyak $10 \%$ dari biomassa bobot tubuh ikan. Pakan yang tersisa kemudian disifon, feses yang dikeluarkan ikan kemudian dikumpulkan dengan cara disifon. Feses yang terkumpul dimasukkan ke dalam botol film dan disimpan dalam freezer untuk menjaga kesegarannya. Setelah jumlah feses yang dikumpulkan dianggap cukup (2 g) maka dilakukan pengeringan. Kemudian dianalisa kandungan $\mathrm{Cr}_{2} \mathrm{O}_{3}$ dan protein feses.
2.4. Parameter yang Diamati

2.4.1. Kecernaan Pakan dan Protein

Kecernaan pakan dan protein dihitung dengan persamaan yang dikemukakan oleh Watanabe (1988) sebagai berikut:

$$
\text { Kpakan }(\%)=\left(1-\mathbf{a} / \mathbf{a}^{\prime}\right) \times 100
$$$$
\text { KProtein }(\%)=\left(1-a^{\prime} / a^{\prime} \times b / b^{\prime}\right) \times 100
$$

Keterangan :

$\mathrm{a}=$ Kadar $\mathrm{Cr}_{2} \mathrm{O}_{3}$ dalam pakan (\%)

$\mathrm{a}^{\prime}=$ Kadar $\mathrm{Cr}_{2} \mathrm{O}_{3}$ dalam feses $(\%)$

$\mathrm{b}=$ Protein dalam pakan $(\%)$

$\mathrm{b}^{\prime}=$ Protein dalam feses $(\%)$

\subsubsection{Efisiensi Pakan}

Menurut Watanabe (1988) rumus menghitung efisiensi pakan adalah :

$$
\mathrm{EP}=\frac{(B t+B d)-B o}{F} \times 100 \%
$$

keterangan:

$$
\begin{aligned}
\mathrm{EP} & =\text { Efisiensi Pakan }(\%) \\
\mathrm{Bt} & =\begin{array}{l}
\text { Bobot biomassa ikan pada akhir } \\
\text { penelitian }(\mathrm{g})
\end{array} \\
\mathrm{Bo}= & \begin{array}{l}
\text { Bobot biomassa ikan pada awal } \\
\text { penelitian }(\mathrm{g})
\end{array} \\
\mathrm{Bd}= & \begin{array}{l}
\text { Bobot biomassa ikan yang mati } \\
\text { selama penelitian }(\mathrm{g})
\end{array} \\
\mathrm{F}= & \begin{array}{l}
\text { Jumlah pakan yang dikonsumsi } \\
\text { ikan selama penelitian }(\mathrm{g})
\end{array}
\end{aligned}
$$

\subsubsection{Retensi Protein}

Retensi protein merupakan perbandingan antara jumlah protein yang 
disimpan ikan didalam tubuh dengan jumlah protein yang diberikan melalui pakan. Retensi protein dapat dihitung dengan rumus Watanabe (1988):

$\mathrm{RP}=\frac{\text { pertumbuhan bobot protein tubuh }(\mathrm{g})}{\text { bobot total protein yang dkonsumsi }(\mathrm{g})} \times 100 \%$

\subsubsection{Laju Pertumbuhan Spesifik}

Menurut Huisman (1976) laju pertumbuhan spesifik diukur dengan menggunakan rumus:

\section{LPS $=(\operatorname{LnWt}-\mathrm{LnWo}) / \mathrm{t} \times 100 \%$}

Keterangan :

LPS $=$ Laju pertumbuhan spesifik (\%)

LnWt = Bobot rata-rata ikan pada akhir penelitian $(\mathrm{g})$

LnWo = Bobot rata-rata ikan pada awal penelitian $(\mathrm{g})$

$\mathrm{t} \quad=$ Lama penelitian (hari)

\subsubsection{Tingkat Kelulushidupan}

Menurut Effendie (2001), tingkat kelulushidupan dapat dihitung dengan rumus sebagai berikut:

$$
S R=\frac{N t}{N o} \times 100 \%
$$

Keterangan:

$\mathrm{SR}=$ Kelulushidupan (\%)

$\mathrm{Nt}=$ Jumlah ikan hidup pada akhir penelitian (ekor)

No = Jumlah ikan hidup pada awal penelitian (ekor)

\subsubsection{Kualitas Air}

Parameter kualitas air yang diukur selama penelitian adalah suhu, $\mathrm{pH}$, dan oksigen terlarut (DO). Pengukuran ini dilakukan di awal, pertengahan dan akhir penelitian.

\subsection{Analisis Data}

Data yang dikumpulkan adalah kecernaan pakan dan protein, efisiensi pakan, retensi protein, laju pertumbuhan spesifik dan kelulushidupan ikan. Data disajikan dalam bentuk tabel dan grafik. Untuk mengetahui pengaruh perlakuan terhadap peubah dilakukan uji ANAVA tetapi sebelumnya diuji normalitas dan homogenitas

\section{Hasil dan Pembahasan \\ 3.1. Kecernaan Pakan dan Protein}

Nilai kecernaan pakan berkisar 59,34$70,23 \%$ dan nilai kecernaan protein berkisar $65,00-81,41 \%$. Nilai kecernaan pakan dan kecernaan protein tertinggi terdapat Pada $\mathrm{P}_{3}$ (80\% tepung kedelai: $20 \%$ tepung lemna) menghasilkan kecernaan pakan 70,23\% dan kecernaan protein $81,41 \%$. Adanya proses fermentasi menghasilkan enzim selulase yang mendegradasi selulosa dalam tepung daun lemna sehingga dapat mengurangi kadar serat kasar. Data mengenai perhitungan kecernaan pakan dan protein pada benih ikan gurami pada setiap perlakuan selama penelitian dapat dilihat pada Tabel 3 .

Tabel 3. Kecernaan Pakan dan Kecernaan Protein Ikan Gurami

\begin{tabular}{ccc}
\hline Perlakuan (\% T K : \% TLF) & Kecernaan Pakan (\%) & Kecernaan Protein (\%) \\
\hline $\mathrm{P}_{0}(100: 0)$ & 59,34 & 65,00 \\
$\mathrm{P}_{1}(90: 10)$ & 61,83 & 71,30 \\
$\mathrm{P}_{2}(85: 15)$ & 65,03 & 76,00 \\
$\mathrm{P}_{3}(80: 20)$ & 70,23 & 81,41 \\
$\mathrm{P}_{4}(75: 25)$ & 67,74 & 78,90 \\
\hline
\end{tabular}

\subsection{Efisiensi Pakan dan Retensi Pakan}

Nilai rata-rata efisiensi pakan ikan gurami (Osphronemus gouramy) yang tertinggi selama penelitian terdapat pada perlakuan P3 (20\% fermentasi tepung daun lemna) yaitu sebesar 40,31\%. Sedangkan retensi protein berkisar antara $28,15-31,05 \%$. Retensi protein tertinggi terdapat pada $\mathrm{P} 3$ (20\% fermentasi tepung daun lemna) yaitu sebesar $31,05 \%$. Lebih jelas dapat dilihat pada Tabel 4.

\subsection{Pertumbuhan Benih Ikan Gurami}

Data pertumbuhan benih ikan gurami didapat setelah melakukan penimbangan yang dilakukan setiap 14 hari selama 56 hari penelitian. Perubahan bobot rata-rata individu ikan uji pada setiap perlakuan dapat dilihat pada Gambar 1. 
Tabel 4. Efisiensi Pakan dan Retensi Protein Ikan gurami

\begin{tabular}{ccc}
\hline Perlakuan (\% T K : \% TLF) & Efisiensi Pakan (\%) & Retensi Protein (\%) \\
\hline $\mathrm{P}_{0}(100: 0)$ & $38,41 \pm 0,51^{\mathrm{a}}$ & $28,15 \pm 0,43^{\mathrm{a}}$ \\
$\mathrm{P}_{1}(90: 10)$ & $39,28 \pm 0,10^{\mathrm{b}}$ & $29,04 \pm 0,44^{\mathrm{b}}$ \\
$\mathrm{P}_{2}(85: 15)$ & $39,58 \pm 0,15^{\mathrm{b}}$ & $29,99 \pm 0,59^{\mathrm{b}}$ \\
$\mathrm{P}_{3}(80: 20)$ & $40,31 \pm 0,16^{\mathrm{c}}$ & $31,05 \pm 0,32^{\mathrm{c}}$ \\
$\mathrm{P}_{4}(75: 25)$ & $39,55 \pm 0,31^{\mathrm{b}}$ & $29,70 \pm 0,55^{\mathrm{b}}$ \\
\hline
\end{tabular}

Keterangan: *huruf superscript yang berbeda pada baris yang sama menunjukkan adanya perbedaan nyata antar perlakuan $(\mathrm{P}<0,05)$

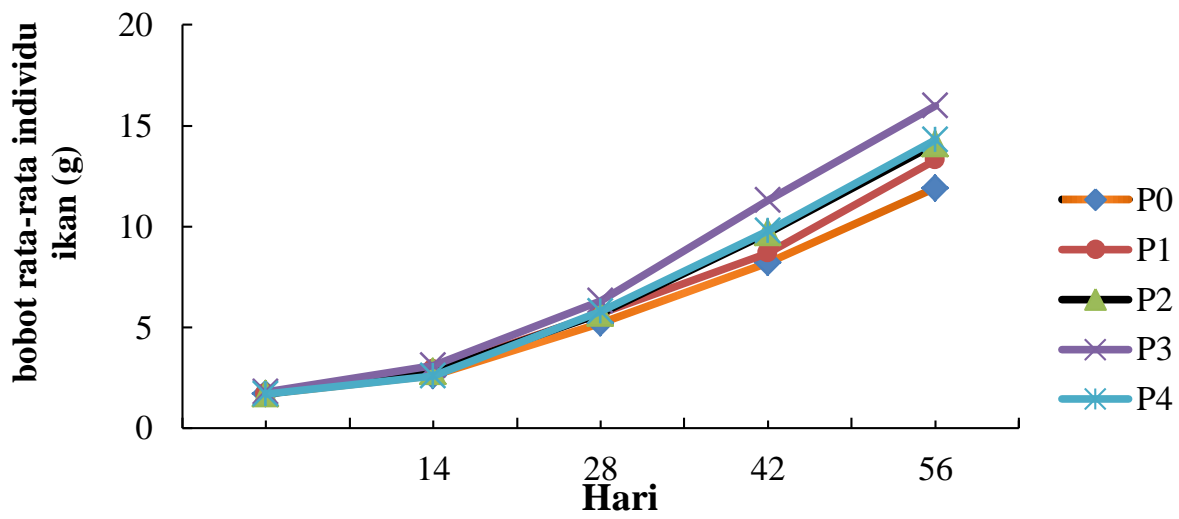

Gambar 1. Bobot Rata-Rata Individu Ikan Gurami

\subsection{Kelulushidupan Ikan Gurami}

Kelulushidupan benih ikan gurami diperoleh dari pengamatan setiap hari dimana semakin berkurangnya ikan uji pada beberapa perlakuan selama penelitian dan diperoleh melalui perhitungan yang dinyatakan dalam persen. Adapun data hasil perhitungan kelulushidupan benih ikan gurami disajikan pada Gambar 2.

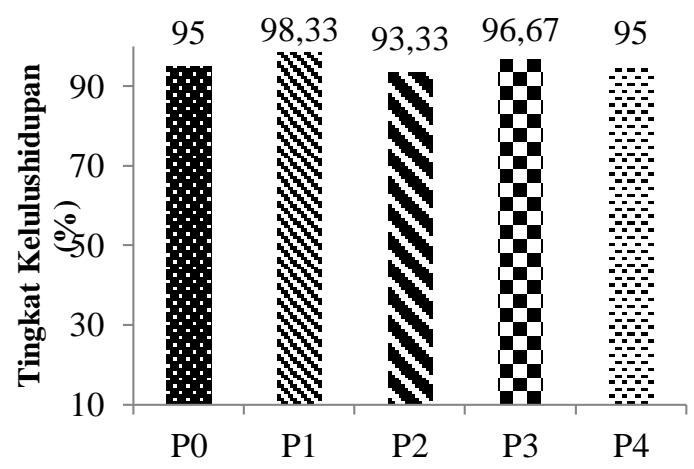

Gambar 2. Tingkat Kelulushidupan Ikan
Menurut Armiah (2010) faktor yang mempengaruhi tinggi rendahnya kelangsungan hidup adalah faktor biotik antara lain kompetitor, kepadatan, populasi, umur dan kemampuan organisme beradaptasi terhadap lingkungan. Namun angka kelulushidupan pada penelitian ini tidak mengartikan bahwa pakan disukai oleh ikan karena dilihat dari pertumbuhan ikan yang baik

\subsection{Kualitas Air}

Faktor kualitas air mempunyai peranan dalam menunjang pertumbuhan dan kelangsungan hidup ikan yang dipelihara. Pengukuran terhadap parameter kualitas air dilakukan untuk mengetahui keadaan air media pemeliharaan. Data hasil Pengukuran kualitas air selama penelitian dapat dilihat pada Tabel 5.

Tabel 5. Data Hasil Pengukuran Kualitas Air selama Penelitian

\begin{tabular}{lllll}
\hline \multirow{2}{*}{ Parameter } & \multicolumn{3}{c}{ Kisaran } & \multirow{2}{*}{ Nilai Standar Pengukuran } \\
\cline { 2 - 4 } & Awal & Pertengahan & Akhir & \\
\hline Suhu $\left({ }^{0} \mathrm{C}\right)$ & $28-31$ & $29-30$ & $29-31$ & $25-30^{\circ} \mathrm{C} *$ \\
$\mathrm{pH}$ & $5-6$ & $5-6$ & 6 & $6-8^{*}$ \\
$\mathrm{DO}(\mathrm{mg} / \mathrm{L})$ & $4-5$ & $4-5$ & 6,8 & $>4^{* *}$ \\
$\mathrm{NH}_{3}(\mathrm{mg} / \mathrm{L})$ & 0,00406 & 0,00406 & 0,00406 & $<0,1^{* * *}$ \\
\hline
\end{tabular}

Keterangan :* Kordi (2010) **Mahyuddin (2010) ***Effendi (2003) 


\subsection{Analisis Biaya Pakan Uji}

Analisis biaya pakan uji pada setiap perlakuan dapat dihitung berdasarkan jumlah komposisi bahan yang digunakan. Biaya pembuatan pakan setiap perlakuan dapat dilihat pada Tabel 6 .

Tabel 6. Analisis Biaya

\begin{tabular}{cc}
\hline $\begin{array}{c}\text { Perlakuan } \\
\text { (\% TK:\% TLF) }\end{array}$ & $\begin{array}{c}\text { Biaya (Rp) / } \\
\text { Kg }\end{array}$ \\
\hline $\mathrm{P}_{0}(100: 0)$ & 9.578 \\
$\mathrm{P}_{1}(90: 10)$ & 8.678 \\
$\mathrm{P}_{2}(85: 15)$ & 8.348 \\
$\mathrm{P}_{3}(80: 20)$ & 8.018 \\
$\mathrm{P}_{4}(75: 25)$ & 7.688 \\
\hline
\end{tabular}

\section{Kesimpulan dan Saran}

Berdasarkan hasil penelitian dapat disimpulkan bahwa ada pengaruh proses fermentasi tepung daun lemna ( $L$. minor) menggunakan rumen sapi untuk menurunkan serat kasar daun lemna. Pemberian 20\% tepung daun lemna terfermentasi dalam pakan uji merupakan perlakuan terbaik yang menghasilkan kecernaan pakan 70,23\%, efisiensi pakan $40,31 \%$, retensi protein $31,05 \%$, dan laju pertumbuhan spesifik ikan gurami $3,77 \%$.

Penulis menyarankan agar adanya penelitian lanjutan penggunaan fermentasi tepung daun lemna sebanyak 20\% dalam pakan yang diaplikasikan pada budidaya ikan gurami sehingga diharapkan dapat menekan biaya pembuatan pakan yang selama ini menggunakan tepung ikan dan tepung kedelai impor.

\section{Daftar Pustaka}

Afrianto, dan E. Liviawaty. (2005). Pakan Ikan. Kanisius. Yogyakarta. $148 \mathrm{hlm}$.

Agustono., A. S. Widodo., dan W. Paramitha. (2010). Kandungan Protein Kasar dan Serat Kasar pada Daun Lemna (Lemna minor) yang Difermentasi. Jurnal Ilmiah Perikanan dan Kelautan, 2(1): 54-57

Akter, M., Chowdhury, S.D Akter and M.A. Katun. (2011). Effect of Duckweed (Lemna minor) Meal in the Diet of Mial in The-Diet of Laying Hen and Their Performances Banglades. Res, Pub. J. 5(3): 252-261.

Agustono, E. Centyana, dan Y. Cahyoko. (2014). Substitusi Tepung Kedelai dengan Tepung Biji Koro Pedang (Canavalia ensiformis) terhadap Pertumbuhan, Survival Rate dan Efisiensi Pakan Ikan Nila Merah. Jurnal Ilmiah Perikanan dan Kelautan, (1):6-14

Armiah, J. (2010). Pemanfaatan Fermentasi Ampas Tahu dalam Pakan terhadap Pertumbuhan Benih Ikan Selais (Ompok hypophthalmus). Skripsi. Fakultas Perikanan dan Ilmu Kelautan Universitas Riau. Pekanbaru.

Boyd. C.E. (1979). Water Quality Management for Pond Fish Culture. Auburn Univ. Agriqulture Experiment Station, Alabama. 359 pp.

Busacker, G.P., I.A.Adelman, dan E. M. Goolish. (1990). Growth. Pages 363377 in C. BSchreck and P.B Moyle, Editors. Methods for fish biology. Ameerican Fisheries Society, Bethesda, Maryland.

Chusniati, S., Kusriningrum., Mustikowein., M. Lamid. (2005). Pengaruh Lama Pemeraman Jerami Padi Difermentasi oleh Isolat Bakteri Selulotik Rumen terhadap Kandungan Protein Kasar dan Serat Kasar. Lembaga Penelitian dan Pengabdian Universitas Airlangga. 49-53.

Daelami, D.A.S. (2001). Agar Ikan Sehat. Penebar Swadaya, Jakarta. $80 \mathrm{hlm}$.

Effendie, M.I. (1992). Metodologi Biologi Perikanan. Yayasan Agromedia. Bogor. $102 \mathrm{hlm}$.

Handajani, H. dan W. Widodo. (2010). Nutrisi Ikan. UMM Press. Malang, $271 \mathrm{hlm}$.

Huisman, E.A. (1976). Food convertion efficiencies at maintenance and production Levels for Carp Cyprinus carpio Linn. and Rainbow Trout Salmo gairdneri Rich. Aquaculture, 9(2): 159273.

Hutapea, S. (1992). Deskripsi dan Seksualitas Sekunder Ikan-Ikan Anabantidae dan Perairan Umum Daerah Riau. Pusat Penelitian Universitas Riau. Pekanbaru. $33 \mathrm{hlm}$.

Kottelat, M.A.J. Whitten., S.N. Kartikasari dan S. Wirjoatmodjo. (1993). Ikan Air Tawar Indonesia Bagian Barat dan Sulawesi. Periplus Editions. $253 \mathrm{hlm}$. 
Landesman, L., N.C., Parker, C.B., Fedler, dan M., Konikoff. (2005). Modeling Duckweed Growth in Wastewater Treatment Systems. Livestock Research for Rural Development, 17:6.

Nalar, H.P., Herliani, I. Bambang, S.R. Rahmatullah, dan Askalani. (2014). Pemanfaatan Cairan Rumen dalam Proses Fermentasi sebagai Upaya Peningkatan Kualitas Nutrisi Dedak Padi untuk Pakan Ternak. Prosiding Seminar Nasional "Inovasi Teknologi Pertanian Spesifik Lokasi”. Banjarbaru, 6 - 7 Agustus 2014.

Nekoubin, H. dan M. Sudagar. (2013). Effect of Different Types of Plants (Lemna sp. Azolla filiculoides and Alfalfa) and Artificial Diet (with Two Protein Levels) on Growth Performance, Survival Rate, Biochemical Parameters and Body Composition of Grass carp (Ctenopharyngodon idella). Journal Aquaculture Researh and Development, 4(2): 6-9.

NRC. (1993). Nutritional Requirement of Warmwater Fishes. National Academic of Science. Washington, D. C. 248 pp.

Pamungkas, W. (2010). Teknologi Fermentasi, Alternatif Solusi dalam Upaya Pemanfaatan Bahan Pakan Alternatif. Loka Riset Pemuliaan dan Tekhnologi Budidaya Perikanan Air Tawar. Sukamandi. Jawa Barat. 113$116 \mathrm{hlm}$.

Said A. (2006). Pengaruh Komposisi Hydrilla verticillata dan Lemna Minor Sebagai Pakan Harian terhadap Pertumbuhan dan Sintasan Ikan Nila Merah (Oreochromis niloticus) dalam Keramba Jaring Apung di Perairan Umum DAS Musi. Peneliti Balai Riset Perikanan Perairan Umum. Prosiding Seminar Nasional ikan IV Jatiluhur.

Setiawaty, J.E., Tarsim, Y.T. Adiputra, dan S. Hudaidah. (2013). Pengaruh Penambahan Probiotik pada Pakan dengan Dosis Berbeda terhadap Pertumbuhan, Kelulushidupan, Efisiensi Pakan dan Retensi Protein Ikan Patin. Jurnal Rekayasa dan Teknologi Budidaya Perairan, 1(2)

Siregar, M.A. (2016). Pengaruh Subtitusi Tepung Kedelai dengan Fermentasi
Tepung Daun Lamtoro Gung (Leucaena leucocephala) dalam Pakan Terhadap Pertumbuhan Benih Ikan Gurami (Osphronemus gouramy Lac.). Skripsi. Fakultas Perikanan dan Ilmu Kelautan Universitas Riau. Pekanbaru. $70 \mathrm{hlm}$.

SNI. (1999). Produksi Benih Ikan Gurami (Osphronemus gouramy) Kelas Benih Sebar. Badan Standarisai Nasional. Jakarta. $13 \mathrm{hlm}$.

Solomon, S.G. and V.T. Okomoda. (2012). Growht Performance of Oreochromis niloticus feed Duckweed (Lemna Minor) Based Diets in Out Door Hapas. International Journal of Research in Fisheris and Aquaculture, 2 (4): 61-65.

Sukran. (2018). Pengaruh Pemberian Tepung Daun Lemna (Lemna minor) dalam Pakan Buatan Terhadap Pertumbuhan Benih Ikan Gurami (Osphronemus gouramy). Skripsi. Fakultas Perikanan dan Kelautan. Universitas Riau. 117 hlm

Sunarma, A. (2004). Penelaahan Sistem Usaha Budidaya Gurame. Balai Budidaya Air Tawar Sukabumi. Sukabumi.

Suprayudi, M.A. (2010). Pengembangan Penggunaan Bahan Baku Lokal untuk Pakan Ikan/Udang: Status Terkini dan Prospeknya. Semi-Loka Nutrisi dan Teknologi Pakan Ikan/Udang. Bogor, Indonesia. Jakarta (ID). Badan Litbang Kelautan dan Perikanan, KKP bekerjasama dengan ISPIKANI.

Sulawesty, F., T. Chrismadha dan E. Mulyana. (2014). Laju Pertumbuhan Ikan Mas (Cyprinus carpio) dengan Pemberian Pakan Lemna (Lemna Perpusilla Torr). Segar pada Kolam Sistem Aliran Tertutup. Jurnal Limnotek, 21(2): 177-184.

Watanabe, T. (1988). Fish Nutrition and Mariculture. Departemen of Aquatic Bioscient. Tokyo University of Fisheries. Jica, 233 pp.

Wuryantoro, S. (2000). Kandungan Protein Kasar dan Serat Kasar Padi Teramonisasi yang Difermentasi dengan Cairan Rumen. Skripsi Universitas Airlangga. Surabaya. 42 hlm. 